\title{
ANALYTIC EVALUATION OF RECTILINEARITY OF LOW RIGIDITY SHAFT DURING HARDENING PROCESS
}

\author{
Antoni Świć', Oleg Draczew², Wiktor Taranenko³, Sadi Majdalawi \\ 1 The Institute of Information Technology Systems, Lublin University of Technology, ul. Nadbystrzycka 36, \\ 20-618 Lublin, Poland, e-mail: a.swic@pollub.pl \\ 2 Togliatti State Technical University, Russia. \\ 3 Luck State Technical University, Ukraine.
}

Received: 2012.11 .23

Accepted: 2012.12 .21

Published: 2013.03.15

\begin{abstract}
The essential influence of the unevenness of temperature distribution while heating in the technological process on dimensions stability of low rigidity elements was shown. The new approach was applied to formulate mathematical models, which describe the elastic and inelastic behaviour of piece using transfer functions and block diagrams, allowing to use frequency method for evaluation of the behaviour of dynamic semifinished element as the rigid body.
\end{abstract}

Keywords: non-rigid shaft, shaft axis rectilinearity, hardening.

\section{INTRODUCTION}

In the long shafts' manufacturing process, rolled semi-finished products which have a considerable curvature when supplied, are used.

Before undergoing machining process, which allows for obtaining a shaft confirming with the assumed tolerance for curvature of its axis, the semi-finished product must undergo straightening process in order to gain the rectilinearity of $0.5 \mathrm{~mm}$ for $1 \mathrm{~m}$ of length $[3,5,7]$.

The disadvantage of straightening by bending is the emergence of irregular residual stress in the longitudinal section of the shaft's semi-finished product. In the machining process, the stress leads to the emergence of bending moment and to the change in the rectilinearity of the shaft's axis $[1,2]$.

\section{ANALYTIC EVALUATION OF THE RECTILINEARITY OF SHAFT'S AXIS DURING HARDENING PROCESS}

Axial straightening is widely implemented. In the process of straightening of a cylindrical semifinished product, all fibers reach the extremes of their plasticity, thus any preexisting axial residual stress is removed. During axial straightening all residual stress is removed when permanent deformation equals $0.5-1 \%[4,6]$.

Research conducted on the heat-stress treatment device $[2,5]$, in case of axial straightening of shafts made of X10CrNi18-8 austenitic steel, is coupled with hardening process (to improve steel's corrosion resistance) but tempering is not required [7]. Austenitic steels possess a high thermal expansion factor and low level of plasticity, thus in order to induce axial stress of straightening after heating up the semi-finished product in the preparation for hardening, the product's extreme ends are fixed in a device made of steel whose thermal expansion factor is lower than the factor of the shaft's product. Cooling of the device is executed with the product fixed to the device. As a consequence of the difference in thermal expansion factors, during cooling process axial force emerges, which brings about axial straightening of shaft's semi-finished product. The aforementioned device consists of a steel 20 pipe with perforations enabling contact with the surrounding environment. Mountings are located at both ends of the device. 
Qualitative axial straightening of shaft's semi-finished product is understood as the process where the result of the operation of axial straightening force is that none of the fibers in every cross-section of the product is under stress exceeding the limit of plasticity. During compression and then stretching, on the surface of any cross-section, stress not lower than the limit of plasticity emerges.

As a maximum input bend of the semi-finished product we understand such initial bend which, in the fiber undergoing extreme compression, brings about stress which does not exceed the limit of plasticity in the temperature corresponding to gaining rectilinearity by the curved axis. Otherwise, a compression cold work emerges in the semi-finished product's cross section, which is not removed in the further stretching processBauschinger effect. As a consequence, an asymmetric crumple zone emerges which corresponds to asymmetric distribution of residual stress, as regards axial symmetry of the cross-section, influencing shaft's rectilinearity. It was established that the bend of the long shaft semi-finished product's axis closely corresponds to the quadratic parabolic equation:

$$
f(z)=y(z)=\frac{4 y_{\max }}{l} \cdot z \cdot\left(1-\frac{z}{l}\right),
$$

where: $y_{\max }-$ maximum output bend of the semifinished product, $l$ - distance between centers of the extreme sections of the shaft, $z$ - current bend value.

Maximum stress emerging in the extreme fiber during stretching process of shaft's bent axis to reach rectilinearity is described as:

$$
\sigma_{\max }=\frac{y_{\max } \cdot F_{r o z}}{W_{x}},
$$

where: $F_{r o z}$-axial force, $W_{\mathrm{x}}$ - shaft semi-finished product's cross-section's strength.

$F_{\text {roz }}$ value is defined in accordance with equation [1] whose transformation gives the following formula:

$$
F_{r o z}=\frac{\left(3 \pi \cdot d^{4} \cdot E\right)}{20 l^{2}},
$$

where: $d$ - shaft semi-finished product's diameter, $E$ - Young's modulus.

Determining the relationship of $l$ to $d$ via $K_{0}$ the following was obtained:

$$
y_{\max } \leq \frac{\left(5 K_{0}^{2} \cdot d \cdot \sigma_{02}\right)}{24 E} .
$$

Due to the fact that maximum compression stress in the compressed fiber emerges during shaft's cooling by temperature $\Delta T^{\circ}$ corresponding to shrinking to the value of maximum initial bend and also shift of $\sigma_{02}$ along with temperature drop $\left(\sigma_{02}=\sigma_{02}(t), E=E(t)\right),(4)$ can be transformed into:

$$
y_{\max } \leq \frac{5 K_{0}^{2} \cdot d \cdot \sigma_{02}\left(t-\Delta T^{\circ}\right)}{24 E\left(t-\Delta T^{\circ}\right)} .
$$

While changing temperature by $\Delta T^{\circ}$, its length will decrease by:

$$
\Delta l=\Delta \alpha(t) \cdot l \cdot \Delta T^{\circ},
$$

where: $\Delta \alpha(t)$ - disparity of thermal expansion factors of device's material and shaft's semi-finished product functionally related to temperature.

Shaft's shortening $\Delta l$ during cooling ought to allow for achieving rectilinearity of the bent axis, i.e.:

$$
\Delta l=\delta_{1}+2 \delta_{2},
$$

where: $\delta_{1}-$ distance required for the "selection" of shaft's semi-finished product's bend, defined as:

$$
\delta_{1}=\frac{8 \cdot \delta_{\max }^{2}}{3 l},
$$

$\delta_{2}$ - backlash between the head of the device and the head of the abutment equal to:

$$
\delta_{2}=\frac{2 d_{w} \cdot \delta_{\max }}{l}
$$

where: $d_{\mathrm{w}}-$ diameter of abutments.

The relationship of the nut's diameter to the diameter of the product was designated as $C$, from (4) $\Delta T^{\circ}$ was defined:

$$
\Delta T^{\circ}=\frac{1}{\Delta \alpha(t) \cdot l^{2}}\left(\frac{8}{3} \delta_{\max }^{2}+4 C \cdot d \cdot \delta_{\max }\right) .
$$

Substituting (8) to (5) and solving $\delta_{\text {max }}$ maximum initial bend of the product was determined as regards its geometry and physical characteristics of the material.

In particular, in case of shaft's semi-finished product made of X10CrNi18-8 steel and the de- 
vice made of steel 20 , they are defined as the following:

$$
\Delta \alpha=1,43 \cdot T^{-0,205}, \quad E=2688 \cdot T^{-0,075}, \quad \sigma_{T}=84,1 \cdot T^{-0,314} .
$$

When comparing values of the initial qualitative bend with the data regarding real semi-finished products made of X10CrNi18-8 steel with the diameter of 20-80 mm and 30/80 length/ diameter ratio, it was determined that semi-finished products whose initial bend is larger than initial qualitative bend exist. Therefore, before conducting long shaft's straightening, shaft's ought to be selected according to their initial bend. In case of X10CrNi18-8 steel shafts, semi-finished products of $1050 \mathrm{~mm}$ length and $30 \mathrm{~mm}$ diameter, their initial qualitative bend ought to amount to no more than $3.4 \mathrm{~mm}$. However, semifinished products whose bend equals $6 \mathrm{~mm}$ and measurements correspond to those above exist.

Semi-finished product's bend which can be made rectilinear by heat-stress processing, provided that such straightening is applied to the product whose initial bend does not exceed the maximum qualitative bend, is defined as the following: when cooling, the shortening of the product ought to compensate for to sum of elongations

$$
\Delta l=\delta_{1}+2 \delta_{2}+\delta_{3}+\delta_{4}
$$

where: $\delta_{3}$ - shortening of the device as a result of implementing a load from the shaft's shortening semifinished product which equals:

$$
\delta_{3}=\frac{\sigma_{02} \cdot l}{E_{p r z} \cdot K_{s}},
$$

where: $\sigma_{\mathrm{T}}$ - the limit of semi-finished product's plasticity at $20^{\circ} \mathrm{C}, E_{\mathrm{prz}}$ - elastic modulus of the device's material at $20^{\circ} \mathrm{C}, K_{\mathrm{s}}$ - device's rigidity vs. semi-finished product's rigidity ratio, $\delta_{4}$ - elongation which ought to be applied to the product so that extreme fibers undergoing compression stress gain stress not lower than the limit of plasticity of the shaft's material at stretching equal to:

$$
\delta_{4}=\frac{\left(\sigma_{k}+\sigma_{02}\right) \cdot l}{E_{20^{0}}},
$$

where: $\sigma_{k}$-stress in the extreme fiber during semi-finished product's maximum bend occurring during stretching to gain rectilinearity.

In accordance with (4) in order to establish $\sigma_{k}$ :

$$
\sigma_{k}=\frac{24 d \cdot E_{t} \cdot \delta_{\max }}{5 l^{2}}
$$

where: $E_{\mathrm{t}}$ - elastic modulus of the shaft's material in heating temperature.

Solving (9) as regards $\delta_{\max }$ the following was obtained:

$$
\begin{aligned}
& \delta_{\max }=-d\left(0.9 \frac{E_{t}}{E_{20}^{0}}+\frac{3}{4} C\right)+ \\
& +d \frac{1}{2} \sqrt{\left(1.8 \frac{E_{t}}{E_{20}^{0}}+1.5 C\right)^{2}+1.5 K_{0}^{2} \frac{\sigma_{02}}{E_{20}^{0}}\left(\frac{\Delta \alpha \cdot t \cdot E_{20}^{0}}{\sigma_{T}}-\frac{E_{20}^{0}}{E_{C T} K_{S}}-1\right)},
\end{aligned}
$$

where: $T$ - heating temperature, $\Delta \alpha$ - disparity of thermal expansion factors of device's material and shaft's semi-finished product in temperature range of $20^{\circ} \mathrm{C}$ to heating temperature.

In order to improve precision and stability of the part's geometric shape of low rigidity, a method coupling straightening and heat treatment was devised. The utilization of the method allows for axial straightening of shaft's semi-finished products during their heat treatment, and improvement of the initial bend of the product as a result of fibers stretching in cross-section up to the limit of plasticity and forming symmetrical residual stress in the product. 


\section{SUMMARY}

Universal equations describing the dynamic system of heat-stress treatment of axiosymmetric parts of low rigidity including changes in their geometric parameters were obtained and analyzed. These relationships allow for the evaluation of secondary defects of elasticity.

A considerable influence of irregularity in the distribution of heating temperature in the technological process on forming spatial stability of low rigidity parts was shown. Application of apriori information does not provide basis for calculations with the required precision due to a considerable spread of physical and mechanical properties and geometric parameters of semifinished products.

Relations of input and output parameters of the controlled subject - a dynamic system, are defined with the use of linear differential equations with constant quadratic and higher coefficients.

Studies in axial straightening of shafts coupled with hardening process (implemented in order to improve corrosion resistance of steel) were carried out in a device for heat-stress treatment device. Suitable relations describing the process were developed.

\section{REFERENCES}

1. Dračev O.I.: Tehnologiâ izgotovleniâ maložestkih osesimmetričnyh detalej. Sankt-Peterburg: Izdatel'stvo Politehnika, 2005, p. 289.

2. Draczow O., Taranenko W.: Technologia modułowa wytwarzania osiowosymetrycznych wałów długowymiarowych. Zesz. Nauk. Politechniki Rzeszowskiej. Mechanika, 230(67), 2006: 47-50.

3. Hałas W., Taranenko G., Taranenko W., Świć A.: Modelowanie poszczególnych operacji procesu technologicznego wytwarzania wałów. Modelowanie inżynierskie, 6(37), 2009: 115-130.

4. Ratchev S., Liu S., Huang W., Becker A.A. Milling error prediction and compensation in machining of low-rigidity parts. International Journal of Machine Tools and Manufacture, 15(44), 2004: 1629-1641.

5. Świć A. Technologia obróbki wałów o małej sztywności. Wydawnictwo Politechniki Lubelskiej, Lublin 2009, p. 144.

6. Taranenko W., Świć A. Urządzenia sterujące dokładnością obróbki części maszyn o małej sztywności. Wydawnictwo Politechniki Lubelskiej, Lublin 2006, p. 186.

7. Taranenko G., Taranenko V., Szabelski J., Swic A.: Indentification and automation of shaft machining in elastic-deformable condition. Information systems architecture and technology, Model Based Decisions, Part IV, Wroclaw Uniwersity of Technolodgy, Wroclaw 2008, p. 203-223. 